\title{
20 anos do curso de Psicologia da Escola Bahiana de Medicina e Saúde Pública
}

\author{
Celebrating the 20th anniversary of the \\ Psychology major of BAHIANA - School \\ of Medicine and Public Health (Brazil)
}

\section{Maria Luisa Soliani}

Escola Bahiana de Medicina e Saúde Pública, Fundação Bahiana para Desenvolvimento das Ciências (Salvador). Bahia, Brasil. mluisasoliani@bahiana.edu.br

Quando recebi o convite de Marilda Castelar e Mônica Daltro para escrever este editorial, aceitei rapidamente. Mas não compreendia exatamente o porquê de ele ter sido feito e nem mesmo porque havia dito sim. Depois, aos poucos, fui me dando conta que fazia sentido, pois estávamos comemorando, com este número da revista, os 20 anos do Curso de Psicologia da Bahiana e eu havia participado desta história, algumas vezes como observador privilegiado, outras, como ator coadjuvante. Enfim, eu estava e continuava por perto. Autorizei-me, então, a dar minha visão dos fatos. E a provocar minha memória para trazer à tona coisas do passado.

Em 1997, nosso Coordenador Geral, Profo Humberto de Castro Lima tinha um sonho, dos muitos que sonhou em sua extensa e profícua vida: o de fazer da Escola Bahiana de Medicina uma universidade.

$\mathrm{Na}$ época, Profo Gáspare Saraceno era o Coordenador de Graduação e eu, de Pósgraduação. Para ser uma universidade, precisávamos ter cursos em várias áreas do conhecimento.
Possuímos medicina, fisioterapia e terapia ocupacional, na saúde, e estávamos num processo para abrir o curso de odontologia. Administração também aparecia no horizonte.

De forma quase natural, surgiu a ideia de criar um curso de psicologia, da área de humanas, pois poderia ter afinidades com nossa expertise na saúde. No entanto, naquele momento, os projetos pedagógicos existentes, possíveis modelos, eram extremamente conservadores, uma soma de disciplinas fragmentadas. Em Salvador, havia um currículo com viés muito forte na clínica psicanalítica e outros dois dedicados à formação de psicólogos para o trabalho.

Fizemos nosso projeto, e ele foi aprovado em dezembro de 1998. Como sempre, em tudo na vida, com percalços. No meio do caminho precisamos encontrar uma nova pessoa para tocá-lo e me lembrei de Rosália. Maria Rosália de Azevedo Correia era psicodramatista, tinha sido minha aluna de psicodrama, havia concluído seu mestrado, coisa bastante rara à época, e, com certeza, seria capaz de transformar aquele projeto inicial em algo mais inovador, menos tradicional. 
Assim aconteceu. A primeira turma começou em 2000, na virada do século, tendo Rosália como coordenadora. Ela imprimiu sua marca, juntando pessoas, ouvindo, motivando, construindo um corpo docente comprometido com a formação e a renovação da maneira de ensinar psicologia. A chegada das diretrizes curriculares de 2004 foram facilmente absorvidas. A abertura para o novo estava presente e eu, até hoje, me lembro, ainda rindo, de uma experiência que vivi.

Tínhamos implantado o PBL (Aprendizagem Baseada em Problemas) no curso de medicina e Rosália estava muito interessada em fazer seus professores conhecerem melhor o método. Com este objetivo, combinamos realizar uma oficina. Já havíamos trabaIhado com os docentes de medicina e a oficina também havia sido ministrada em um Fórum Pedagógico da Bahiana, para professores de vários cursos, com muito sucesso. Profa Maria Suzana Vasconcelos, fisioterapeuta, dava aula de anatomia e de metodologia científica no curso de medicina e era minha parceira nestes treinamentos. Chegamos para o trabalho com os docentes certas de que daria tudo certo. Mas foi um desastre. O problema tinha se saído muito bem nas oficinas anteriores, mas ali não funcionava. Nos demos conta, após a leitura do texto, no passo previsto para o levantamento do problema, de que aquilo que era claro e não suscitava nenhum questionamento para os professores dos demais cursos, era o problema para os psicólogos. Ele estava nos detalhes, nos subentendidos, no oculto e não dito. Foi assustador e engraçado, mas aprendemos muito e refizemos tudo para o dia seguinte. O PBL sobreviveu. Em 2009.1, foi implantado.

O tempo passou e o curso foi se firmando. No segundo semestre de 2009, assumiu como coordenadora a Profa Mônica Daltro. Ela trouxe consigo novas ideias, como a do internato em psicologia, e deu ênfase na questão da pesquisa, estimulando seus docentes a se abrirem para a necessidade de pesquisar como parte do trabalho do professor. Durante sua gestão, uma nova reforma curricular foi realizada, tendo sua personalidade forte, seu dinamismo, competência, visão humanística e abrangente, além da capacidade de mobilizar e entusiasmar pessoas, como motores principais.

2014 chega com Sylvia Barreto. E, com ela, uma nova marca. Uma condução feita com leveza, calma e enorme capacidade de ouvir e encontrar caminhos de consenso e corresponsabilização. Mas não nos enganemos. A mão é firme e os pés bem plantados no real.

Foram 20 anos de desafios, propostas, mudanças e realizações. Construímos um curso de forma coletiva, tendo como atores principais seus professores e alunos, regidos por três maestrinas tão diferentes, mas tão iguais em seus ideais de formar profissionais e cidadãos éticos, comprometidos com uma psicologia plural, pautada em conhecimento científico, aberta à interlocução com outros saberes, capaz de se ver nas interfaces dos fenômenos culturais, políticos, sociais, econômicos, biológicos, ambientais. Uma psicologia não alienada nem alienante. Inventamos um curso de psicologia que hoje é referência de qualidade em nível nacional, motivo de orgulho para todos.

O Mestrado Profissional em Psicologia e Intervenções em Saúde e a Revista Psicologia, Diversidade e Saúde, que agora apresenta este número especial, são os frutos mais jovens. A RPDS é uma revista aberta, acessível a quem desejar lê-la, assim como as outras editadas pela Bahiana, pois acreditamos na ciência disponibilizada para todos e não encastelada, trancada em si mesma, usufruída apenas por uns poucos que possam pagar. Ciência deve estar em todos os lugares e ser propriedade do mundo.

Esta é a minha versão da história. A história de um sonho e de uma caminhada que começou no século passado e continuará se fazendo e refazendo pelo andar de muitos pés, mãos, corações e mentes em direção a um futuro que espero, cheia de esperança, seja mais justo, solidário e inclusivo.

Feliz aniversário! 